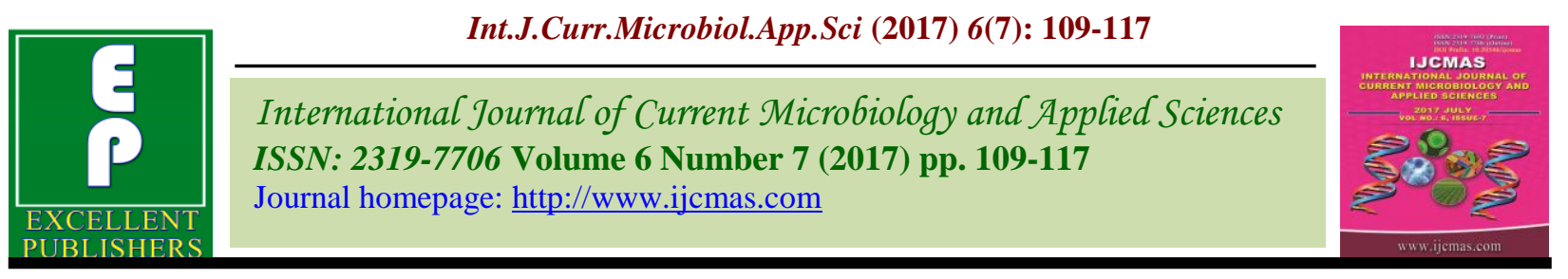

Review Article

https://doi.org/10.20546/ijcmas.2017.607.013

\title{
A critical review on effect of fertilizers and plant densities on growth, yield and yield attributes of cucurbitaceous crops
}

\author{
M. Siva*, T.S.K.K. Kiran Patro, M.M. Nagaraju, T. Thomson, \\ G. Koteswara Rao and N. Emmanuel
}

\author{
College of Horticulture, Dr.YSR Horticultural University, Venkataramanna Gudem-53410, \\ West Godavari, A.P., India \\ *Corresponding author
}

\begin{tabular}{|c|c|}
\hline & $\mathbf{T} \mathbf{R} A \mathbf{C}$ \\
\hline & \multirow{6}{*}{$\begin{array}{l}\text { Cucurbits comprise } 117 \text { genera and } 825 \text { species. Out of this } 30 \text { species of nine genera are } \\
\text { used as cultivated plants. Most of the cucurbits viz., cucumber, bottle gourd, ridge gourd, } \\
\text { bitter gourd, snake gourd, water melon and muskmelons are monoecious and annul in } \\
\text { habit. However plants like pointed gourd, spine gourd, ivy gourd and chow-chow are } \\
\text { dioecious and perennials. It is of high market demand with a special delicacy for the } \\
\text { people of India and it fetches premium price in the market. Though are potential vegetable } \\
\text { crops, there is not much standardized scientific cultivation technology available for } \\
\text { improving the yield. Agro techniques like nutrition and spacing play an important role in } \\
\text { commercial production. Spacing is an important factor which will influence the plant } \\
\text { population and affect the nutrient uptake in plants by creating competition between plants } \\
\text { for nutrients, water and availability of light to the plants for synthesizing the food. By } \\
\text { manipulation of inter and intra row spacing, several workers reported higher yields. Under } \\
\text { field conditions, optimum nitrogen, phosphorus and potassium should be supplied to } \\
\text { overcome the bottleneck of production. Several workers reported higher yields with } \\
\text { nutrients. However, information on spacing, nitrogen, phosphorus and potassium } \\
\text { requirements of pointed gourd, spine gourd, chow-chow and ivy gourd is scarce under } \\
\text { Indian conditions. The relevant literature pertaining to the fertilizer and plant densities on } \\
\text { growth, yield and yield attributes is reviewed and presented here under with the following } \\
\text { sub-heads. Fertilizer studies on growth, yield and yield attributes of cucurbits. Plant } \\
\text { density studies on growth, yield and quality yield attributes of cucurbits. Interaction } \\
\text { studies between different fertilizer and plant densities on growth, yield and yield attributes } \\
\text { of cucurbits. }\end{array}$} \\
\hline & \\
\hline $\begin{array}{l}\text { Fertilizers, } \\
\text { Plant densities, } \\
\text { Cucurbits, } \\
\text { Growth and yield. }\end{array}$ & \\
\hline Article Info & \\
\hline $\begin{array}{l}\text { Accepted: } \\
\text { 04 June } 2017 \\
\text { Available Online: } \\
\text { 10 July } 2017\end{array}$ & \\
\hline & \\
\hline
\end{tabular}

\section{Introduction}

Cucurbits are important and big group of vegetable crops cultivated exclusively in the sub-tropical and tropical countries. These are annual, semi perennial and perennial vegetable crops. These are monoecious and dioecious vegetables which are grown for its taste and nutritive value. The center of origin is tropical Africa. This group consists of wide range of vegetables, either used as salad (Cucumber) or for cooking (all the gourds) or pickling (cucumber) or for desert fruits (muskmelon and water melon) which are more popular now a days. Most of the cucurbits viz., cucumber, bottle gourd, ridge gourd, bitter gourd, snake gourd, water melon and muskmelons are monoecious and annual 
in habit. However plants like pointed gourd, spine gourd, ivy gourd and chow-chow are dioecious and perennial vegetables. They include mostly seed propagated ones, besides few vegetatively propagated like pointed gourd, spine gourd, ivy gourd and chowchow. The cucurbits are long tap root system. Leaves are dark green, simple cordate, ovate and oblong. Flowers are tubular, white and fruits are round, oblong and smooth. Cucurbits are high nutrient vegetables compared to other vegetables as it is rich in proteins, vitamin $\mathrm{A}$ and $\mathrm{C}$, fat, carbohydrates and minerals like calcium, potassium and phosphorus (Singh, 1989). In severe winter it becomes dormant and sprouts again in summer and it is available for ten months in a year i.e. February to November. The green tender and mature fruits are consumed as a vegetable. However new tender shoots and leaves are also used as vegetable. It is easily digestible with good diuretic and laxative properties and also invigorates the heart and brain and is useful in the disorders of the circulatory system. The fruits also possesses anti - cancer properties. Its roots also used in treatment of jaundice besides the leaves reduce blood sugar levels. Due to its high medicinal value, it is becoming popular day by day in the country (Kumar, 2011).

\section{Fertilizer studies}

Growth is an irreversible increase in size, shape of the plant and it is affected by the complex interaction between environmental factors and physiological processes which are influenced by the application of external inputs like water and nutrients.

Das et al., (1987) studied $N$ at $0,30,60$ or 90 $\mathrm{kg} \mathrm{ha}^{-1}, \mathrm{P}_{2} \mathrm{O}_{5}$ at $0,20,40$ or $60 \mathrm{~kg} \mathrm{ha}^{-1}$ and basal $\mathrm{K}_{2} \mathrm{O}$ at $40 \mathrm{~kg} \mathrm{ha}^{-1}$. The crop was harvested 150 days later. Plant growth and yield increased with rising $\mathrm{N}$ : P rates, with the maximum average early yield (45.9 q ha $\left.{ }^{-1}\right)$ and total yield (138.8 $\left.\mathrm{q} \mathrm{ha}^{-1}\right)$ being obtained at 90:60 $\mathrm{kg} \mathrm{ha}^{-1}$ in pointed gourd.

Kumar et al., (1990) investigated $\mathrm{N}$ at 0, 30, 60 or $90 \mathrm{~kg} \mathrm{ha}^{-1}$ and $\mathrm{P}_{2} \mathrm{O}_{5}$ at $0,20,40$ or $60 \mathrm{~kg}$ $\mathrm{ha}^{-1}$. Half of $\mathrm{N}$ and entire $\mathrm{P}$ plus $\mathrm{K}_{2} \mathrm{O}$ at $40 \mathrm{~kg}$ $\mathrm{ha}^{-1}$ were applied at planting and the remaining $\mathrm{N}$ was applied 60 days later. The number of fruits plant ${ }^{-1}$ increased from 111.3 at zero $\mathrm{N}$ to 167.16 at $60 \mathrm{~kg} \mathrm{~N} \mathrm{ha}{ }^{-1}$ and declined to 165.44 at the highest $\mathrm{N}$ rate. With $\mathrm{P}$, the number of fruits plant ${ }^{-1}$ increased from 130.82 at zero $P$ to 150.8 at the highest $P$ rate in pointed gourd.

Tripathy et al., (1993) found that NPK each at $30 \mathrm{Kg} \mathrm{ha}^{-1}$ gave higher yield and longest fruits while plant height and leaf area were greater with $\mathrm{N}, \mathrm{P}_{2} \mathrm{O}_{5}$, and $\mathrm{K}_{2} \mathrm{O}$ each at $60 \mathrm{~kg}$ $\mathrm{ha}^{-1}$ level in spine gourd.

Misra et al., (1994) reported that the application of $150 \mathrm{~kg} \mathrm{~N} \mathrm{ha}^{-1}, 35 \mathrm{~kg} \mathrm{Pha}^{-1}$ and $67 \mathrm{~kg} \mathrm{~K} \mathrm{ha}^{-1}$ gave the highest yield and fruit quality in the Parwal.

Tripathy et al., (1994) reported that 30:30:30 NPK kg ha ${ }^{-1}$ was best for higher fruit yield in pointed gourd. Fruit yield was highly and positively correlated with plant height, leaf area, fruit plant ${ }^{-1}$ and fruit weight.

Goswami and Sharma (1997) reported increased fruit yield in spine gourd with increased levels of $\mathrm{P}_{2} \mathrm{O}_{5}$ upto $60 \mathrm{Kg} \mathrm{ha}^{-1}$ and $\mathrm{K}_{2} \mathrm{O}$ upto $75 \mathrm{~kg} \mathrm{ha}^{-1}$ and no significant interaction was observed between $\mathrm{P}$ and $\mathrm{K}$. Further, revealed that neither $\mathrm{P}$ nor $\mathrm{K}$ had a significant effect on the length of the main vine and $\mathrm{K}$ had no effect on ascorbic acid content but this was highest when $\mathrm{P}$ was applied at $40 \mathrm{~kg} \mathrm{P}_{2} \mathrm{O}_{5} \mathrm{ha}^{-1}$.

Choudhari and More (2002) revealed that highest vine length, fruit diameter, fruit weight, number of fruits per vine, yield per 
vine and yield $\mathrm{ha}^{-1}$, and highest nutrient content in the crop, as well as the lowest nutrient residues in the soil after harvest were recorded when 200:125:125 $\mathrm{kg} \mathrm{NPK} \mathrm{ha}^{-1}$ was applied in cucumber.

Das et al., (2004) investigated the influence of nitrogen and phosphorus fertilization on growth and yield of pointed gourd and observed that plant growth and yield increased with rising $\mathrm{N}: \mathrm{P}$ rates and with the maximum average early yield (45.9 $\mathrm{q} \mathrm{ha}^{-1}$ ) and total yield (138.8 $\left.\mathrm{q} \mathrm{ha}^{-1}\right)$ at 90:60 $\mathrm{kg} \mathrm{ha}^{-1}$.

Umamaheswarappa et al., (2005) found that nitrogen levels had a significant effect on number of days required for initiation of first male and female flowers, number of male and female flowers per vine, number of days required for fruit set. The phosphorus levels also showed positive effect on number of male and female flowers vine ${ }^{-1}$, fruit set per cent and sex ratio in cucumber cv. Poinsette.

El-Gengaihi et al., (2007) found that highest number of fruits was produced with use of the combined medium nitrogen dose and high potassium doses.

The obtained data revealed that higher fruit number with higher fresh and dry weight could be obtained by adding nitrogen at 200 $\mathrm{kg}$ acre $^{-1}$ with potassium at a rate of $100 \mathrm{~kg}$ acre $^{-1}$ bitter gourd.

Shivashankaramurthy et al., (2007) recorded that the combination of NPK has showed significant effect on vegetative characters like number of pistillate flowers, leaf chlorophyll content, yield attributes such as number of fruits, fruit weight and yield in gherkin and concluded that NPK@175:125:125 kg ha ${ }^{-1}$ is the optimal level for good yield and quality of fruits in gherkin. Vishwakarma et al., (2007) with the $80 \mathrm{~kg} \mathrm{~N} \mathrm{ha}^{-1}$ as well as $60 \mathrm{~kg} \mathrm{P}_{2} \mathrm{O}_{5}$ $\mathrm{ha}^{-1}$ recorded least number of days taken for germination, first female flower anthesis and first harvest; and highest mean values for number of nodes to first female flower, number of fruits plant $^{-1}$, fruit length, fruit diameter, average fresh weight, yield plant $^{-1}$, vine length, estimation of chlorophyll and total soluble solids. Treatment combination $\left(80 \mathrm{~kg} \mathrm{~N} \mathrm{ha}^{-1}+60 \mathrm{~kg} \mathrm{P}_{2} \mathrm{O}_{5} \mathrm{ha}^{-1}\right)$ emerged as superior over all other treatment combinations in relation to growth, yield attributing components, yield and quality for cultivation of spine gourd.

Hilli et al., (2009) reported that higher dose of fertilizer (100:100:100 $\mathrm{kg} \mathrm{ha} \mathrm{ha}^{-1}$ resulted significantly more vine length, higher fruit and seed yield compared to other levels of fertilizers in ridge gourd.

Jilani et al., (2009) indicated that NPK fertilizer (100-50-50) application in cucumber showed the best performance in almost all the parameters studied, as it took least days for flowering (39.33), fruit setting (11.55), maturity (7.88), maximum fruit plant $^{-1}(35.5)$, maximum fruit length $(18.36 \mathrm{~cm})$, maximum fruit weight (136.03 g) and yield ha ${ }^{-1}(60.02)$ tons.

Rahul et al., (2010) recorded that the interaction combinations of N P K $(200 \mathrm{~kg} \mathrm{~N}$ $\mathrm{ha}^{-1}+50 \mathrm{~kg} \mathrm{P}_{2} \mathrm{O}_{5} \mathrm{ha}^{-1}+100 \mathrm{~kg} \mathrm{~K}_{2} \mathrm{O} \mathrm{ha}{ }^{-1}$ ) recorded the maximum weight of fruit $(230.45 \mathrm{~g})$ and maximum number of fruits plant $^{-1}$ (13.81) in cucumber cv. Japanese long green.

Sanap et al., (2010) reported that the number of branches, diameter of fruit, yield vine ${ }^{-1}$ and yield ha ${ }^{-1}$ were highest when $250 \mathrm{~kg} \mathrm{~N}, 50 \mathrm{~kg}$ $\mathrm{P}_{2} \mathrm{O}_{5}$ and $100 \mathrm{~kg} \mathrm{~K}_{2} \mathrm{O}$ ha $^{-1}$ was applied in bitter gourd.

Sharma and Sharma (2010) found the highest plant height $(58.88 \mathrm{~cm})$ was observed at $100 \%$ recommended dose of NPK (125-75-60 
$\mathrm{kg} \mathrm{ha} \mathrm{h}^{-1}$ ) compared to lower doses in cauliflower. Rani et al.,(2012) concluded that in pointed gourd the $100 \%$ fertigation through drip significantly maximum fruit length $(10.55 \mathrm{~cm})$, fruit width $(3.96 \mathrm{~cm})$, average fruit weight $(38.50 \mathrm{~g})$, weight of fruits vine ${ }^{-1}$ $(6.31 \mathrm{~kg})$ and yield $\left(15.78\right.$ tons $\left.\mathrm{ha}^{-1}\right)$.

Kumar et al., (2012) revealed that in bottle gourd the application of organic manures alone or in combination with half of recommended dose of NPK enhanced the growth and yield attributes in bottle gourd over full dose of recommended NPK (100:50:50 kg ha ${ }^{-1}$ ) and were significantly at par with $10 t \mathrm{FYM}+$ half RDF.

Higher yields can only be obtained with the use of organic manures in combination with chemical fertilizers.

Sureshkumar and Johnson naorem (2015) found that Phosphorus $90 \mathrm{~kg} \mathrm{ha}^{-1}+$ Potassium $80 \mathrm{~kg} \mathrm{ha}^{-1}$ registered the maximum values in growth parameters viz., vine length, number of branches plant ${ }^{-1}$, number of leaves plant ${ }^{-1}$ in bitter gourd.

Maluki et al., (2015) concluded that $50 \mathrm{Kg}$ $\mathrm{P}_{2} \mathrm{O}_{5} \mathrm{ha}^{-1}$ and120 Kg N ha ${ }^{-1}$ had a positive significant effect on number of days to flowering, number of fruits plant $^{-1}$, fruit weights, firmness, rind thickness, total soluble solids and no significant difference in sex expression ratio in water melon.

\section{Plant density studies}

Plant density/spacing significantly influences the productivity per unit area by decreasing or increasing the availability of total assimilates to fruits.

Moerman (1984) reported that fruit numbers $\mathrm{m}^{2}$ were greatest at a spacing of $46 \mathrm{~cm}$, but subsequently the closest spacing gave the best results.

Differential effects of spacings on fruit storage quality were slight in cucumber.

Yadav et al., (1989) reported that spaced at $1.5 \times 1.5 \mathrm{~m}$ or $3.0 \times 1.5 \mathrm{~m}$, were trained on the flat or on the bower system. Data are tabulated on the number of shoots plant ${ }^{-1}$, vine length, days to flower initiation, days to first picking, fruit length, diameter and weight, number of fruits plant ${ }^{-1}$, and fruit yield. The highest yields (136.3 q ha ${ }^{-1}$ ) were obtained at the closer spacing in pointed gourd.

Pandit et al., (1997) found that the total and early fruit yields were highest (101.71 and $169.82 \mathrm{q} / \mathrm{ha}$, respectively) when plants were spaced $0.60 \mathrm{~m}$ apart in rows in pointed gourd.

Dash et al., (2000) noticed that the spacing of $150 \mathrm{~cm}$ proved to be the most effective in pointed gourd and 15 female plants around one male was found to be best.

Jan et al., (2000) observed that plant spacing of $50 \mathrm{~cm}$ in bottle gourd had significant influence on days to germination, fruit weight (gm), fruit volume $(\mathrm{ml})$, number of fruits vine ${ }^{-}$ ${ }^{1}$, vine length $(\mathrm{cm})$ and yield $\mathrm{ha}^{-1}$. Increasing plant spacing increased all the above mentioned parameters, except yield ha ${ }^{-1}$.

Dash and Tripathy (2001) denoted that four densities: 5, 10, 15 and 20 for every male plant at three spacings: 90, 120 and $150 \mathrm{~cm}$ around a single male plant at the centre in a circular manner. The increase in distance of female plant from the male plant increased the vine length, number of branches and leaves plant $^{-1}$, number of female flowers and yield. However, planting 15 female plants $150 \mathrm{~cm}$ away from the male plant at the centre records the maximum yield in pointed gourd.

Choudhari and More (2002) concluded that 
the highest number of fruits per vine, yield vine $^{-1}$, yield $\mathrm{ha}^{-1}$, vine length, content of nutrients in the plant after harvesting and lowest residues of nutrients in the soil were recorded in $1.80 \mathrm{~m} \times 0.45 \mathrm{~m}$ spacing in cucumber.

Gebologlu and Salgam (2002) found that highest fruit yield was obtained from the 20 $\mathrm{cm}$ within row spacing and $75 \mathrm{~cm}$ between rows spacing in cucumber.

Ravikumar et al., (2005) found that spacing of $1.50 \mathrm{~m} \times 0.5 \mathrm{~m}$ recorded higher fruit yield (154.9 $\left.\mathrm{q} \mathrm{ha}^{-1}\right)$, seed setting $(84.1 \%)$ and seed yield $\left(76.6 \mathrm{~kg} \mathrm{ha}^{-1}\right)$ though lower in fruit length $(18.9 \mathrm{~cm})$ and diameter $(19.7 \mathrm{~cm})$ as compared to wider spacing $1.50 \times 0.75 \mathrm{~m}$. in cucumber.

Dev (2011) reported that among spacing i.e., $100 \mathrm{~cm} \times 100 \mathrm{~cm}, 150 \mathrm{~cm} \times 100 \mathrm{~cm}$ and $200 \mathrm{~cm}$ $\mathrm{x} 100 \mathrm{~cm}$, the wide spacing recorded significant difference with maximum yield of $200.1 \mathrm{q} \mathrm{ha}^{-1}$ with 37.4 fruits of an average weight $116.2 \mathrm{~g} \mathrm{plant}^{-1}$ in bitter gourd.

Kleiton et al., (2013) reported that in water melon the total yield of fruit $\mathrm{ha}^{-1}$ was higher in 1000 plant/ha $(66.7$ t) compared to 500 plant/ha $(33.57 \mathrm{t})$.

Nweke et al., (2013) showed that in cucumber number of branches, number of leaves and vine length decreased as the plant spacing increased from $50 \mathrm{~cm} \times 30 \mathrm{~cm}$ to $50 \mathrm{~cm} \times 40 \mathrm{~cm}$. The closest plant spacing $(50 \mathrm{~cm} \times 30 \mathrm{~cm})$ recorded the highest value in all the parameters assessed in this trial except for number of flowers, Days to $50 \%$ anthesis, length of fruit and weight of fruit in cucumber.

Sylvestre et al., (2014) found that spacing of $1 \mathrm{~m} \times 2 \mathrm{~m}$ gave the highest number of fruits and yield (28.59 $\left.\mathrm{t} \mathrm{ha}^{-1}\right)$ in water melon.
Aniekwe and Anike (2015) revealed that plant spacing $50 \mathrm{~cm} \times 40 \mathrm{~cm}$ gave rise to a profuse branched plants with longer vines $(144.7 \mathrm{~cm})$, greater number of leaves (35.2) and leaf area $\left(181.05 \mathrm{~cm}^{2}\right)$, while fruit length of $20.4 \mathrm{~cm}$ and the highest fruit diameter $(9.53 \mathrm{~cm})$ resulted from the widest plant spacing of 50 $\mathrm{cm} \times 50 \mathrm{~cm}$. The closest plant spacing $(50 \mathrm{~cm}$ $\mathrm{x} 30 \mathrm{~cm}$ ) consistently produced the lowest values in all the vegetative and yield parameters considered except in fruit weight $(1.0 \mathrm{~kg})$ in of cucumber.

Oga and Umekwe (2016) reported that spacing at $50 \mathrm{~cm} \times 60 \mathrm{~cm}$ significantly increased the number of leaves and $50 \%$ anthesis. Spacing at $50 \mathrm{~cm} \times 60 \mathrm{~cm}$ was the adequate measurement for minimizing days to $50 \%$ flowering (37.19 days) and maximizing total number of fruits (2.94), weight of fruits $(3.03 \mathrm{~kg})$ and total yield $\left(7.57 \mathrm{~kg} \mathrm{ha}^{-1}\right)$. Plant spacing at $50 \mathrm{~cm} \times 40 \mathrm{~cm}$ consistently gave the least values in all the yield parameters measured except on the number of fruits in water melon.

Interaction effects between different fertilizers and plant densities on growth, yield and yield attributes of cucurbitaceous crops

Vishnu Shukla and Prabhakar (1987) reported that $\mathrm{N}: \mathrm{P}_{2} \mathrm{O}_{5}: \mathrm{K}_{2} \mathrm{O}$ at either 180:100:100 kg $\mathrm{ha}^{-1}$ as a full dose or one-third of this amount as a reduced dose and spacing the plants at $300 \times 45 \mathrm{~cm}$ with one plant hill $^{-1}$ gave the highest average yield of $384.54 \mathrm{q} \mathrm{ha}^{-1}$. The average yield was $385.37 \mathrm{q} \mathrm{ha}^{-1}$ with the full dose of NPK and $300.74 \mathrm{q} \mathrm{ha}^{-1}$ with the reduced dose in bottle gourd.

Jan et al., (2000) obtained that NPK fertilizer doses has significant effect on days to germination, fruit weight $(\mathrm{gm})$, fruit volume $(\mathrm{ml})$, number of fruits vine ${ }^{-1}$, vine length $(\mathrm{cm})$ and yield $\mathrm{ha}^{-1}$ (tones). Increasing NPK 
fertilizer doses also increased the above mentioned parameters. Maximum yield (20.403 t ha-1) was obtained from (164-114164NPK $\mathrm{kg} \mathrm{ha}{ }^{-1}$ ). Plant spacing had significant influence on days to germination, fruit weight $(\mathrm{gm})$, fruit volume $(\mathrm{ml}$,$) number$ of fruits vine $\mathrm{e}^{-1}$, vine length $(\mathrm{cm})$ and yield $\mathrm{ha}^{-1}$. Increasing plant spacing increased all the above mentioned parameters, except yield $\mathrm{ha}^{-1}$. Maximum yield (19.709 $\mathrm{t} \mathrm{ha}^{-1}$ ) was obtained from $(50 \mathrm{~cm})$ in bottle gourd.

Choudhari and More (2002) studied spacing and fertilizer requirement of cucumber hybrids. The highest number of fruits $v^{-1} e^{-1}$, yield vine ${ }^{-1}$, yield ha ${ }^{-1}$, vine length, content of nutrients in the plant after harvesting and lowest residues of nutrients in the soil were recorded in $1.80 \mathrm{~m} \times 0.45 \mathrm{~m}$ spacing. The highest vine length, fruit diameter, fruit weight, number of fruits vine ${ }^{-1}$, yield vine ${ }^{-1}$ and yield $\mathrm{ha}^{-1}$, and highest nutrient content in the crop, as well as the lowest nutrient residues in the soil after harvest were recorded when 200:125:125 kg NPK ha ${ }^{-1}$ was applied.

Sabo et al., (2013) reported that the interaction between the treatments indicated that $150 \mathrm{~kg} \mathrm{ha}^{-1}$ of NPK and a spacing of $1 \times$ $1.5 \mathrm{~m}$ gave the highest number of fruits and yield $\mathrm{ha}^{-1}$. Therefore, based on the result of these findings, it is hereby recommended that the use of $150 \mathrm{~kg} \mathrm{NPK} \mathrm{ha}^{-1}$ at a spacing of 1 $\times 1.5 \mathrm{~m}$ should be adopted by the farmers for profitable watermelon production.

\section{References}

Aniekwe, N.L and Anike, N.T. 2015. Effects of Different Mulching Materials and Plant Densities on the Environment, Growth and Yield of Cucumber. Journal of Agriculture and Veterinary Science (IOSR-JAVS).8(11): 64-72.

Choudhari, S. $M$ and More, T.A. 2002.
Fertigation, fertilizer and spacing requirement of tropical gynoecious cucumber hybrids. Acta Horticulturae.233-240.

Das, M. K, Maity, T. K and Som, M. G. 2004. Growth and yield of pointed gourd (Trichosanthes dioica Roxb.) as influenced by nitrogen and phosphorous fertilization. Vegetable Science. 14(1):18-26.

Das, M. K., Maity, T. K and Som, M. G.1987. Growth and yield of pointed gourd (Trichosanthes dioica Roxb.) as influenced by nitrogen and phosphorus fertilization.

Vegetable Science.14(1):18-26.

Dash, S. K and Tripathy, L. 2001. Studies on different plant density models on growth and flowering of pointed gourd (Trichosanthes dioica Roxb.) South Indian Horticulture. 49: 55-57.

Dash, S. K., Saheb, S. K, Tripathy, M. K. 2000. Effects of different plant density models on growth and flowering of pointed gourd. (Trichosanthes dioica Roxb.) Madras Agricultural Journal. Vol. 86(4/6) pp. 282-286

Dev, H. 2011. Effect of spacing and pit size on yield and its attributes in bitter gourd cv. Solan Hara. Agricultural science digest. 31(1):40-43.

El-Gengaihi, S., Hendawy, S and Kamel, A. 2007. Effect of nitrogen and potassium fertilization on the yield and quality of Momordica charantia fruits. Department of Medicinal and Aromatic Plants National Research Centre. Herba rolonic.53 (1).

Gebologlu, N and Saglam, N. 2002.The effect of different plant spacing and mulching materials on the yield and fruit quality of pickling cucumber. Acta Horticulturae. pp. 603-607.

Goswami, P.K and Sharma, S. 1997. Effect of phosphorous and potash on growth, yield and quality of spine gourd. 
Horticulture Journal. 10(2):101-106.

Hazra, P., Chattopadhyay, A., Karmakar and Dutta, S. 2011. Modern technology in vegetable production. New India publishing Agency. Pitam pura, New Delhi.pp.380-384.

Hilli, J.S., Vyakarnahal, B.S., Biradar,D.P and Ravi Hunje. 2009. Influence of method of trailing and fertilizer levels on seed yield of ridge gourd (Luffa acutangula L.Roxb). Karnataka J.Agric.Sci. 22(1):47-52.

Jan, M., Iqbal M., Ghafoor, N.D., Waseem, A., Jillani, K., M.S and Khan, D.I. 2000. Effect of NPK fertilizers and spacing on the yield of bottle gourd (Lagenaria siceratia M). Pakistan journal of biological sciences 3(3):448449.

Jilani, M.S., A. Bakar, K. Waseem and Kiran, M. 2009. Effect of different levels of N, $\mathrm{P}, \mathrm{K}$, on the growth and yield of cucumber (Cucumis sativus) under the plastic tunnel. J. Agric. Soc. Sci., 5: 9910.

Kleiton, Rocha Saraiva., Thales Vinícius de, Araújo Viana., Solerne, Caminha Costa., Evando, Luiz Coelho., Cristiane, Aires Celedonio., Gregório, Hermes., Paiva, de Lima. 2013. Influence of density planting the culture of watermelon on characteristics of production in the Chapada Do Apodi, Ce Rev. Bras. Agric. Irrigada.7(2):129136.

Kumar, M and Sharma, N.K. 2015.The response of Nitrogen levels and plant spacing on flowering and dry matter content of fruit of bottle gourd cultivars. Annals of Agri-Bio Research. 20(1):4850

Kumar, N. 2011. Pointed gourd (Trichosanthes dioica Roxb).An over view. Inter Journal of Pharma and Bio Scinces.2 (3):111-118.

Kumar, S. C. P., Krishnappa, K. S., Reddy, N.
S and Anjanappa, M. 2004. Effect of varying levels of NPK on growth and yield of ridge gourd in southern dry region of Karnataka. Mysore Journal of Agricultural Sciences. 38(4):446-453.

kumar, V., Vinay kumar Singh and Teena rani. 2012. Effect of integrated nutrient management on Economics in Bottlegourd (Lagenaria siceraria L.). Environment and ecology. 30(4a):1410-1412.

Laghari, M.H., Mugheri, A.A., Sheikh, S.A and Wahocho, N.A. 2014. Response of nitrogen levels on the growth and yield of bottle gourd varieties. International journal of Agronomy and Agricultural Research (IJAAR) 5(6):86-92.

Lane and Eyon (AOAC).1965. Association of official Agricultural Chemists. Official Methods of Analysis AOAC, Washington D C.

Latifi, M., Barimavandi, A., Sedaghathoor, S and Lipayi, S.R. 2012. Sowing date and plant population effects on seed yield of Cucurbita pepo. Int. J. Agric. Biol., 14: 641-644.

Lowry, O.H., Rosebrough, N.J., Farr, A.L and Randall, R.J. 1951. Analytical techniques for bio chemical constituents. Journal of Biochemistry. 193: 265.

Maluki, M., Gesimba, R.M and Ogweno, J.O. 2015. Effects of nitrogen and phosphorous on yield and quality of watermelon [Citrullus lanatus (Thunb.) Matsumara and Nakai]. I.J.S.N., 6 (2):188-194.

Marschner, H. 1983. General introduction to the mineral nutrition of plants. Inorganic plant nutrition. A. Kauchli and R.L. Bielashki (Eds). Springer Verlag, New York 15: 109-111.

Massri, M and Labban, L. (2014). Comparison of Different Types of Fertilizers on Growth, Yield and Quality Properties of Watermelon 
(Citrllus lanatus). Agricultural Sciences. 5: 475-482.

Maynard, G., Hale and David, M., Orcutt. 1987. in the physiology of plants under stress. A Wiley Inter Science Publications, New York pp 71-72 and 145-166.

Mendlinger, S. 1994. Effect of increasing plant density and salinity on yield and fruit quality in muskmelon. Scientia Horticulturae. 57 (1-2):41-49.

Mia, B., M.A., Serajul Islam, Md., YunusMiah, Md., Das, M.R and Khan, H.I. 2014. Flower synchrony, growth and yield enhancement of small type bitter gourd (Momordica charantia L.) through plant growth regulators and NPK fertilization. Pakistan journal of biological sciences. 17(3):408-413.

Misra, R.S., Kumar, R., siohi, R.K and Misra, S.P. 1994. Nutrinational studies in parwal (Trichosanthes Dioica Roxb). Recent Hort. 1(1):58-60.

Moerman, P. A.1984. Plant spacing with cucumbers on substrate. Groenten en Fruit.40(14): 42-43.

Mondal,B., Das, R., Saha, G and Khatua, D.C. 2014. Downy mildew of pointed gourd and its management. Scholars Academic Journal of Biosciences (SAJB).2(6):389-392.

Nweke, I.A., Orji, E.C and Ijearu, S.I. 2013. The effect of staking and plant spacing on the growth and yield of cucumber (Cucumis sativus L.) Journal of Environmental Science, Toxicology and Food Technology. 3(4):26-31.

Oga, I.O and Umekwe, P. N. 2016. Effects of pruning and plant spacing on the growth and yield of watermelon (Citrullus lanatus L.) in Unwana-Afikpo. International Journal of Science and Research. 5 (4):110-115.

Pandit, M. K., Som, M. G and Maity, T. K. 1997. Effect of plant densities on growth and yield of pointed gourd
(Trichosanthes dioica Roxb.). Horticultural Journal.10(2): 89-92.

Patro, T. S. K. K. K and Mallareddy, K. 2009. Effect of spacing and fertilizers on yield attributing characters in kakrol (Momordica dioica Roxb.) The Andhra agric.j 56(4):480-492.

Rahul, A., kade, A and Devi Singh. 2010. Influence of interaction effect of NPK on number of fruits per vine and weight of fruit in cucumber (Cucumis sativus 1.) cv. japanese long green.Veg. Sci. 37(1):69-71.

Rani, R., Nirala, S.K and Suresh, R. 2012.Effect of fertigation and mulch on yield of pointed gourd in calcareous soil of North Bihar. Environment and Ecology. 30(3A):641-645.

Ravikumar, G.H., Gouda, M.S., Vasudevan,N., owda, B and Reddy, M. 2005. Influence of spacing, nipping and fruit retention on seed yield and seed quality in cucumber. Seed Research. 33 (1):82-87.

Sabo, M.U., Wailare, M.A., Aliyu, M., Jari, S and Shuaibu, Y. M. 2013. Effect of NPK fertilizer and spacing on growth and yield of watermelon (Citrillus lanatus L.) in Kaltungo Local Government area of Gombe State, Nigeria Scholarly Journal of Agricultural Science 3(8):325-330.

Sanap, K.S., Warade, S.D., Sanap, P.B., Barkule, S.R and Pandhre, G.R. 2010. Effect of N, P and $\mathrm{K}$ on Growth and Yield of Bitter gourd (Momordica charantia L.).Bioinfole. 7 (2):184-185.

Sharma, K. C and Sharma, L. K. 2010. Effect of bio-fertilizers and NPK levels on growth and yield of mid-maturity group of cauliflower under mid hill sub-humid conditions of Himachal Pradesh. Journal of Hill Agriculture. 1(1):19-22.

Shivashankaramurthy, T.C., Nagegowda, V., Basavaiah and Farooqui, A.A. 2007. Influence of nitrogen, phosphorous and 
potassium on the yield and quality of gherkin.Indian Journal of Horticulture. 64(2):228-230.

Singh, A.K.1989. Pointed gourd (Trichosanthes dioica Roxb.) Indian Hortic. 33: 35-38.

Sureshkumar, R and Johnson, naorem. 2015. Effect of phosphorus and potassium on growth and yield characters of bitter gourd (Momordica charantia 1.) Ecotype mithipagal. The Asian Journal of Horticulture. 10 (2). 207-211.

Sylvestre, H., Bosco, N.J., Emmanuel, N and Christine, U. 2014. Growth and yield of Watermelon as affected by different spacing and mulching types under Rubona conditions in Rwanda Scholarly Journal of Agricultural Science.4 (10):517-520.

Tripathy, P., Maharana, T., Nandi, A and Dora, D.K. 1993. Effects of cutting, node number and fertilizer on spine gourd (Momordica dioica Roxb.) Indian Journal of Agricultural Sciences. 6397: 432-43.

Tripathy, P., Maharana, T., Singh, D. N and Nandi, A. 1994. Effect of sex type and IBA on rooting of pointed gourd (Trichosanthes dioica Roxb.) stem cuttings. Vegetable Science. 21 (1): 2931.

Umamaheswarappa, V., Nache Gowda, V., Venkatesha Murthy, $P$ and Pitchai Muthu, M. 2005. Effect of Varied Levels of Nitrogen, Phosphorus and Potassium on Flowering, Fruit Set and Sex Ratio of Cucumber. Karnataka Journal of Agricultural Sciences.18 (3):744-747.

Vishnu Shukla. H and Prabhakar, B. S.1987. Effect of plant spacing and fertilizer on yield of bottle gourd. South Indian Horticulture.35(6):453-454.

Vishwakarma, S. K., Gautam, D.S., Yadav, N.S and Gautam, S.S. 2007. Effect of different levels of nitrogen and phosphorus on growth, yield and quality of spine gourd (Momordica dioica Roxb.) Technofame - A Journal of Multidisciplinary Advance Research, pp: 120-123.

Yadav, J. P., Singh, K and Jaiswal, R. C.1989.Influence of various spacings and methods of training on growth and yield of pointed gourd (Trichosanthes dioica Roxb.). Vegetable Science.16(2):113-118.

\section{How to cite this article:}

Siva, M., T.S.K.K. Kiran Patro, M.M. Nagaraju, T. Thomson, G. Koteswara Rao and Emmanuel, N. 2017. A Critical Review on Effect of Fertilizers and Plant Densities on Growth, Yield and Yield Attributes of Cucurbitaceous Crops. Int.J.Curr.Microbiol.App.Sci. 6(7): 109117. doi: https://doi.org/10.20546/ijcmas.2017.607.013 